\title{
Role of de novo biosynthesis in ecosystem scale monoterpene emissions from a boreal Scots pine forest
}

\author{
R. Taipale ${ }^{1}$, M. K. Kajos ${ }^{1}$, J. Patokoski ${ }^{1}$, P. Rantala ${ }^{1}$, T. M. Ruuskanen ${ }^{1,2}$, and J. Rinne ${ }^{1}$ \\ ${ }^{1}$ University of Helsinki, Department of Physics, P.O. Box 64, 00014 University of Helsinki, Finland \\ ${ }^{2}$ University of Innsbruck, Institute of Ion Physics and Applied Physics, Technikerstr. 25, 6020 Innsbruck, Austria
}

Received: 15 October 2010 - Published in Biogeosciences Discuss.: 1 November 2010

Revised: 11 August 2011 - Accepted: 15 August 2011 - Published: 18 August 2011

\begin{abstract}
Monoterpene emissions from Scots pine have traditionally been assumed to originate as evaporation from specialized storage pools. More recently, the significance of de novo emissions, originating directly from monoterpene biosynthesis, has been recognized. To study the role of biosynthesis at the ecosystem scale, we measured monoterpene emissions from a Scots pine dominated forest in southern Finland using the disjunct eddy covariance method combined with proton transfer reaction mass spectrometry. The interpretation of the measurements was based on a correlation analysis and a hybrid emission algorithm describing both de novo and pool emissions. During the measurement period May-August 2007, the monthly medians of daytime emissions were $200,290,180$, and $200 \mu \mathrm{g} \mathrm{m}^{-2} \mathrm{~h}^{-1}$. The emissions were partly light dependent, probably due to de novo biosynthesis. The emission potential for both de novo and pool emissions exhibited a decreasing summertime trend. The ratio of the de novo emission potential to the total emission potential varied between $30 \%$ and $46 \%$. Although the monthly changes were not significant, the ratio always differed statistically from zero, suggesting that the role of de novo biosynthesis was observable. Given the uncertainties in this study, we conclude that more accurate estimates of the contribution of de novo emissions are required for improving monoterpene emission algorithms for Scots pine dominated forests.
\end{abstract}

\section{Introduction}

Monoterpenes are estimated to be major contributors to aerosol particle formation and growth (e.g. Tunved et al., 2006; Hallquist et al., 2009), often cited as the key

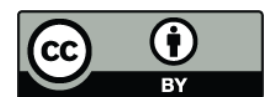

Correspondence to: R. Taipale (risto.taipale@ helsinki.fi) uncertainty in current climate change research. Over the years, numerous studies have focused on monoterpene emissions from the Eurasian boreal zone, nowadays recognized as an important but still poorly characterized source (for a review, see Rinne et al., 2009). Long-term ecosystem scale flux measurements are a welcome addition to these studies due to their spatial representativeness and capability to reveal seasonal changes.

The disjunct eddy covariance method (DEC; Rinne et al., 2001; Karl et al., 2002) has been widely applied to volatile organic compound (VOC) flux measurements at the ecosystem scale. It has usually been combined with proton transfer reaction mass spectrometry (PTR-MS), which is an online technique for measuring VOC concentrations (Lindinger et al., 1998; de Gouw and Warneke, 2007; Blake et al., 2009). This combination has yielded fundamental information on VOC emissions from various ecosystems (e.g. Warneke et al., 2002; Spirig et al., 2005; Holzinger et al., 2006; Brunner et al., 2007; Rinne et al., 2007; Davison et al., 2009; Bamberger et al., 2010; Holst et al., 2010; Langford et al., 2010; Misztal et al., 2010).

Scots pine is one of the dominant evergreen tree species in Eurasian boreal forests. Its monoterpene emissions have traditionally been assumed to originate as evaporation from specialized storage pools and thus modelled with temperature dependent algorithms (e.g. Tingey et al., 1980; Guenther et al., 1991, 1993). However, there is increasing evidence that a substantial part of these emissions stems directly from monoterpene biosynthesis in a light and temperature dependent manner, without intermediate storage in specialized storage pools (Steinbrecher et al., 1999; Shao et al., 2001; Ghirardo et al., 2010). These de novo emissions have been described using both the traditional synthesis algorithm of Guenther et al. $(1991,1993)$ and more process-based algorithms including different physiological, phenological, and biochemical details of monoterpene biosynthesis (e.g. Niinemets et al., 2002; Bäck et al., 2005; Grote et al., 2006).

Published by Copernicus Publications on behalf of the European Geosciences Union. 
The two origins of monoterpene emissions have been combined in hybrid algorithms which describe both pool and de novo emissions (e.g. Shao et al., 2001; Schurgers et al., 2009; Ghirardo et al., 2010).

A recent study demonstrated, using ${ }^{13} \mathrm{CO}_{2}$ labelling and PTR-MS analysis, that the ratio of de novo emissions to total emissions can be over $50 \%$ for Scots pine saplings (Ghirardo et al., 2010). It also indicated that a hybrid algorithm can track ecosystem scale measurements better than a traditional pool algorithm. This paper attempts to estimate the contribution of de novo biosynthesis directly from DEC measurements during the summer 2007. We first analyse whether the measured emissions had a light dependent component and then utilize a simple hybrid algorithm (Ghirardo et al., 2010) to examine seasonal changes in the proportion of de novo emissions and in the normalized emission, i.e. the emission potential. This information could be useful when improving biological realism and ecosystem scale parameterizations in regional and global monoterpene emission inventories (Arneth et al., 2008; Niinemets et al., 2010a,b).

\section{Methods}

\subsection{Flux measurements}

The SMEAR II (Station for Measuring EcosystemAtmosphere Relations II) station of the University of Helsinki served as the measurement site (for a review, see Hari and Kulmala, 2005). It was situated at a rather homogeneous 45-year-old Scots pine (Pinus sylvestris) dominated forest in southern Finland $\left(61^{\circ} 51^{\prime} \mathrm{N}, 24^{\circ} 17^{\prime} \mathrm{E}, 180 \mathrm{~m}\right.$ a.s.1.). The forest had a relatively open canopy with a dry needle biomass density of $540 \mathrm{~g} \mathrm{~m}^{-2}$ (in 2005; Rinne et al., 2007) and an average tree height of $16 \mathrm{~m}$. The stand also contained some Norway spruce (Picea abies), silver and downy birch (Betula pendula and pubescens), common aspen (Populus tremula), and grey alder (Alnus incana). The undergrowth consisted mainly of cowberry (Vaccinium vitis-idaea), bilberry (Vaccinium myrtillus), and mosses (Pleurozium schreberi, Dicranum polysetum).

The monoterpene flux measurements were conducted about $6 \mathrm{~m}$ above the forest canopy using the DEC method (Rinne et al., 2001; Karl et al., 2002). The measurement setup consisted of a sonic anemometer (Gill Instruments Ltd., Solent HS1199) and a PTR-MS instrument (Ionicon Analytik GmbH; Hansel et al., 1995; Lindinger et al., 1998). The heated sampling line was $30 \mathrm{~m}$ long, $8 \mathrm{~mm}$ in inner diameter, operating at a continuous flow of $17.51 \mathrm{~min}^{-1}$, and made of Teflon (PTFE). A side flow of about $90 \mathrm{ml} \mathrm{min}^{-1}$ was taken into the PTR-MS through PTFE tubing, which was $1.3 \mathrm{~m}$ in length and $1.6 \mathrm{~mm}$ in inner diameter. The total monoterpene concentration was derived from the molecular ion signal detected at $137 \mathrm{amu}$ using an integration (dwell) time of $0.5 \mathrm{~s}$. The flux averaging time was $45 \mathrm{~min}$. Our DEC methods have been described in detail by Rinne et al. (2007) and Taipale et al. (2010). The PTR-MS measurement, calibration, and concentration calculation methods have been presented by Taipale et al. (2008).

The measurement period was May-August 2007. The longest breaks were 26-27 June, 22-27 August, and 2930 August. Only every third hour was allocated for the flux measurements since the PTR-MS was utilized also in concentration profile and shoot scale emission measurements. All flux measurements indicating emission were included in the later analysis without applying any quality criterion, i.e. only negative values were filtered out. These negative fluxes made up $20 \%$ of the whole data and $80 \%$ of them were observed at night (20:00-08:00). The final data included 151 observations from May, 159 from June, 176 from July, and 117 from August. The dismissal of the flux quality control was deemed justified as filtering based on the atmospheric stability, the friction velocity, or the monoterpene flux uncertainty (Taipale et al., 2010) would have distorted the flux distribution by eliminating many near-zero observations. In total, these quality criteria would have eliminated $23-42 \%$ of the data, which also would have decreased the statistical significance of the analysis (see Sect. 3.2).

\subsection{Hybrid emission algorithm}

To estimate the contribution of de novo biosynthesis to the total ecosystem scale emissions, a simple hybrid emission algorithm was fitted to the flux measurements. The applied hybrid algorithm was the one formulated by Ghirardo et al. (2010) starting from the pool and synthesis algorithms developed by Guenther et al. (1991, 1993). A formulation with only two free parameters, both related to emission potentials, was chosen to achieve statistically significant results. The original constant values (Guenther, 1997) were used for the parameters related to the emission activity factors.

The hybrid algorithm assumes that the monoterpene emission, $E$, has two independent origins, de novo biosynthesis and evaporation from specialized storage pools:

$E=E_{\text {synth }}+E_{\text {pool }}=E_{0, \text { synth }} C_{\mathrm{T}} C_{\mathrm{L}}+E_{0, \text { pool }} \gamma$.

Here $E_{0 \text {,synth }}$ and $E_{0 \text {,pool }}$ are the emission potentials for de novo and pool emissions. The synthesis activity factors for temperature and light, $C_{\mathrm{T}}$ and $C_{\mathrm{L}}$, are the same as in the traditional synthesis algorithm (Guenther et al., 1991, 1993). They describe the dependence of enzyme activity on temperature and the dependence of electron transport rate on light. The temperature activity factor, $\gamma$, has the same form as in the traditional pool algorithm (Guenther et al., 1991, 1993). It describes the dependence of monoterpene saturation vapour pressure on temperature.

Equation (1) can be converted into the final hybrid formulation of Ghirardo et al. (2010):

$E=E_{0}\left[f_{\text {synth }} C_{\mathrm{T}} C_{\mathrm{L}}+\left(1-f_{\text {synth }}\right) \gamma\right]$. 
Here $E_{0}=E_{0 \text {,synth }}+E_{0 \text {,pool }}$ is the total emission potential and $f_{\text {synth }}=E_{0, \text { synth }} / E_{0}$ is the ratio of the de novo emission potential to the total emission potential.

In addition to Eq. (2), the traditional pool algorithm, $E_{\text {pool }}=E_{0, \text { pool }} \gamma$, was fitted to the measured emissions to have a point of comparison. It has been the established choice for Scots pine, especially when interpreting measurements (e.g. Janson, 1993; Rinne et al., 2000, 2007; Ruuskanen et al., 2005; Tarvainen et al., 2005; Hakola et al., 2006; Räisänen et al., 2009). The hybrid algorithm is a more recent option, introducing de novo biosynthesis and thereby light dependence into the traditional monoterpene algorithm. Over the years, various hybrid formulations have been used, and not solely for Scots pine and monoterpenes (e.g. Schuh et al., 1997; Shao et al., 2001; Spanke et al., 2001; Haapanala et al., 2009; Schurgers et al., 2009).

To reveal seasonal changes in the monoterpene emissions, $E_{0}, f_{\text {synth }}$, and $E_{0, \text { pool }}$ were determined for May, June, July, and August using non-linear regression in the least squares sense. The $95 \%$ confidence interval was calculated for each parameter to estimate whether the changes were statistically significant. The regression analysis was based on the Levenberg-Marquardt method (e.g. Seber and Wild, 1989). The initial value was $10 \%$ for $f_{\text {synth }}$ and $100 \mu \mathrm{g} \mathrm{m}^{-2} \mathrm{~h}^{-1}$ for $E_{0}$ and $E_{0 \text {,pool }}$. No predetermined upper or lower limits were used for these parameters. The regression and confidence interval calculations were conducted using the MATLAB functions "nlinfit" and "nlparci".

The values of the other algorithm parameters, including the standard temperature and light $\left(30^{\circ} \mathrm{C}\right.$ and $\left.1000 \mu \mathrm{mol} \mathrm{m} \mathrm{m}^{-2} \mathrm{~s}^{-1}\right)$ and the temperature dependence coefficient in $\gamma\left(0.09^{\circ} \mathrm{C}^{-1}\right)$, were taken from Guenther (1997). Half-hour averages of air temperature (at $8.4 \mathrm{~m}$ ) and photosynthetically active radiation (PAR, at $74 \mathrm{~m}$ ) were used as the input variables in the algorithms. They were acquired from a set of SMEAR II routine measurements (Junninen et al., 2009). Differences in PAR within the canopy were not considered when fitting the algorithms and bark biomass was not used as a proxy for storage pools.

\section{Results and discussion}

\subsection{Emissions, temperature, and PAR}

Figure 1 shows the monoterpene emissions, air temperature, and PAR during the summer 2007. The emissions were highest during the sunny and warm periods when the maximum temperatures were around $25^{\circ} \mathrm{C}$. At the onsets and ends of these periods, the changes in all three variables were distinct and rather coincident. However, the steep rise in the temperature in early May was not reflected on the emissions.

The range of the emissions was roughly 50$600 \mathrm{\mu g} \mathrm{m}^{-2} \mathrm{~h}^{-1}$ in the daytime. Previous shoot and ecosystem scale measurements at the site have yielded quite similar results (e.g. Rinne et al., 2000, 2007; Spanke et al., 2001; Ruuskanen et al., 2005; Tarvainen et al., 2005; Hakola et al., 2006). For instance, when multiplied by the needle biomass density $\left(540 \mathrm{~g} \mathrm{~m}^{-2}\right)$, the daytime emissions from Scots pine branches reported by Hakola et al. (2006) were typically $100-750 \mu \mathrm{g} \mathrm{m}^{-2} \mathrm{~h}^{-1}$ in May-August. On the other hand, the monoterpene emissions from the forest floor measured by Hellén et al. (2006) were clearly below $50 \mu \mathrm{g} \mathrm{m}^{-2} \mathrm{~h}^{-1}$ in summer. Thus we may suggest, consistently with Rinne et al. (2007), that the ecosystem scale emissions originated mainly from the aboveground biomass, i.e. from Scots pine needles and bark.

The monthly medians of the daytime emissions for MayAugust were 198, 292, 182, and $204 \mu \mathrm{g} \mathrm{m}^{-2} \mathrm{~h}^{-1}$ (Table 1). As indicated by the $95 \%$ confidence intervals, the daytime median for June was significantly higher than the values for May and July. Otherwise the daytime medians did not differ statistically from each other at the $95 \%$ confidence level. The daytime values were significantly higher than the night-time values, which illustrates the diurnal variation in the emissions. The differences between the medians calculated from all measurements were not significant, except for the increase between May and June.

Previous long-term shoot scale measurements at the site have shown a fairly clear seasonal cycle with peak emissions between late June and early August (Tarvainen et al., 2005; Hakola et al., 2006). Now the emissions peaked already in June, otherwise their monthly medians remained essentially invariable over the summer. This slight discrepancy vanishes when the emission potentials are considered, which indicates that the results do not differ much after the normalization to the standard light and temperature conditions (see Sect. 3.2).

The monthly medians of temperature and PAR (Table 1) were calculated using the observations concurrent with the measured emissions. The median daytime temperatures for May-August were $12.3,17.8,17.6$, and $20.9^{\circ} \mathrm{C}$. This increasing trend was significant at the $95 \%$ confidence level. The monthly daytime medians of PAR were 767, 1192, 706, and $762 \mu \mathrm{mol} \mathrm{m}^{-2} \mathrm{~s}^{-1}$. The median for June was statistically higher than the other values, which were alike at the $95 \%$ confidence level. A similar seasonal pattern was observed in the monoterpene emissions.

Table 1 also shows the correlation coefficients between the emissions, temperature, and PAR for each month. Based on the confidence intervals, the correlations were significant but did not have clear diurnal or seasonal variations. The range was $0.43-0.66$ for the emission-temperature correlation, $0.35-0.51$ for the emission-PAR correlation, and 0.240.68 for the temperature-PAR correlation. The emissiontemperature correlation for the daytime measurements in May and the night-time measurements in June and July as well as the daytime temperature-PAR correlation for May were not significant. Also the differences between the emission-temperature, emission-PAR, and temperaturePAR correlations were insignificant. This indicates a large 


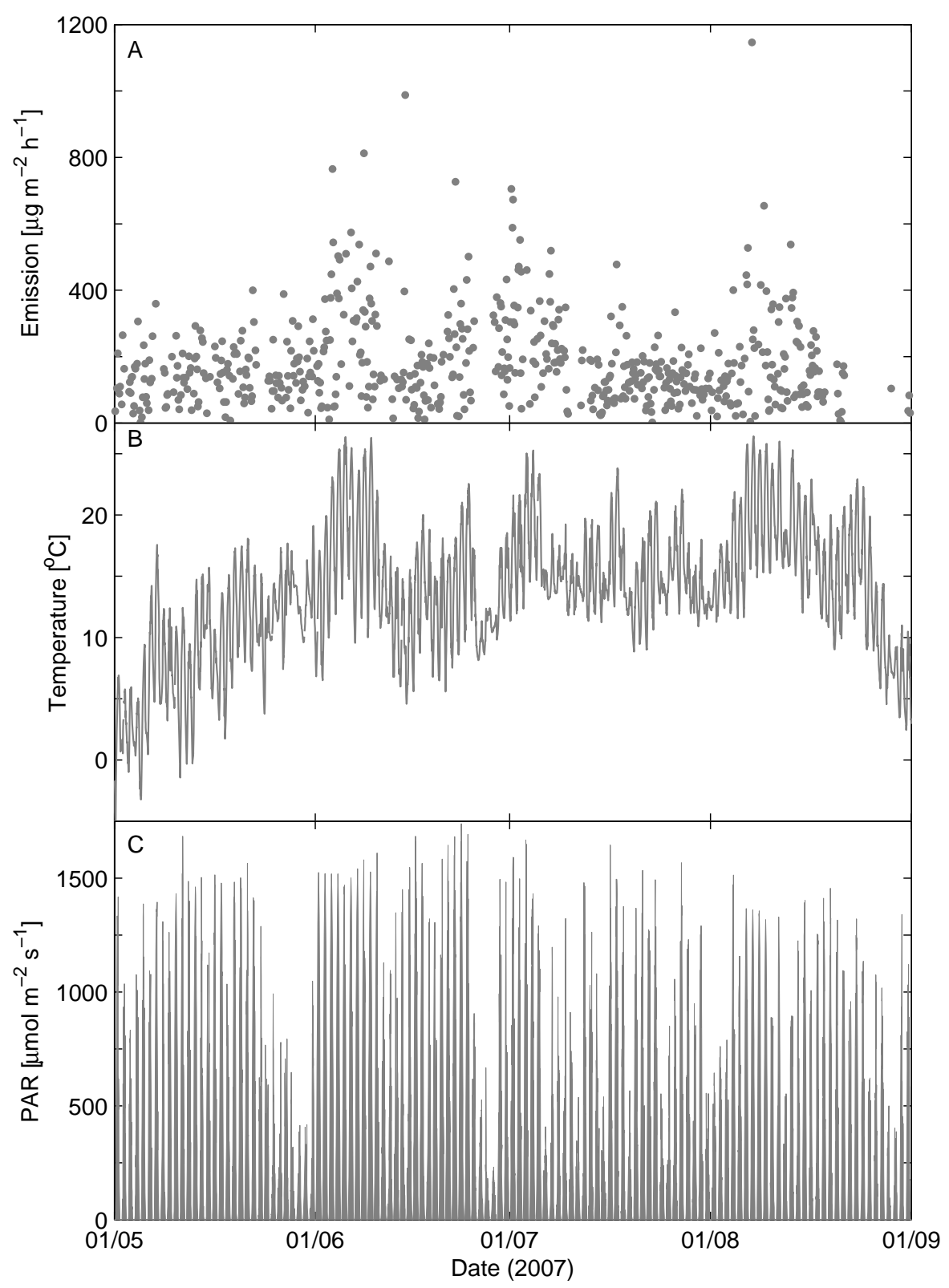

Fig. 1. Monoterpene emissions, air temperature, and photosynthetically active radiation (PAR) during the summer 2007.

uncertainty in the estimates of the contribution of de novo emissions determined with the non-linear regression analysis (see Sect. 3.2). Further measurements are needed to reveal reasons for the insignificant night-time emissiontemperature correlations.

Figure 2 illustrates the emission-PAR correlation in three narrow temperature ranges. A similar analysis was performed for six other ranges between 8 and $26^{\circ} \mathrm{C}$. All PAR observations above $10 \mu \mathrm{mol} \mathrm{m}^{-2} \mathrm{~s}^{-1}$ were included in the analysis. In addition to the three examples in Fig. 2, the emission-PAR correlation was significant in the ranges $10-12$ and $16-18^{\circ} \mathrm{C}$. The correlation coefficients were $0.38(0.08-0.61)$ and $0.25(0.03-0.45)$, respectively.
The emission-temperature and temperature-PAR correlations were insignificant in all nine temperature ranges, indicating that the temperature dependence did not interfere with this analysis. Similarly, the emission-PAR and temperaturePAR correlations were insignificant in the PAR ranges 200 $400,600-800$, and $1000-1200 \mu \mathrm{mol} \mathrm{m}^{-2} \mathrm{~s}^{-1}$. The emissiontemperature correlations in these ranges were $0.38(0.17-$ $0.55), 0.45(0.13-0.68)$, and $0.41(0.10-0.65)$.

The medians in Fig. 2 indicate that the emissions at high PAR were statistically higher than the emissions at low PAR. A similar increase was present also in the ranges 10-12 and $16-18^{\circ} \mathrm{C}$. Based on the correlations and medians in the different temperature ranges, it seems that the ecosystem scale 
Table 1. Monthly medians and correlations of the monoterpene emissions, air temperature, and photosynthetically active radiation (PAR) during the summer 2007. The values represent all, daytime (12:00-16:00), and night-time (00:00-04:00) measurements. The $95 \%$ confidence intervals are in parentheses. Only statistically significant $(p<0.05)$ correlation coefficients $(r)$ are shown.

\begin{tabular}{|c|c|c|c|c|}
\hline & May & June & July & August \\
\hline & \multicolumn{4}{|c|}{ Median emission $\left(\mu \mathrm{g} \mathrm{m}^{-2} \mathrm{~h}^{-1}\right)$} \\
\hline all & $140(126-154)$ & $182(157-207)$ & $150(137-164)$ & $138(116-160)$ \\
\hline day & $198(172-224)$ & $292(243-340)$ & $182(146-218)$ & $204(149-258)$ \\
\hline \multirow[t]{2}{*}{ night } & $86(63-109)$ & $70(44-100)$ & $113(83-144)$ & $54(37-71)$ \\
\hline & \multicolumn{4}{|c|}{ Median temperature $\left({ }^{\circ} \mathrm{C}\right)$} \\
\hline all & $10.4(9.4-11.4)$ & $15.2(14.4-16.0)$ & $15.3(14.8-15.8)$ & $17.7(16.8-18.5)$ \\
\hline day & $12.3(11.1-13.6)$ & $17.8(16.7-18.9)$ & $17.6(16.6-18.5)$ & $20.9(19.2-22.7)$ \\
\hline \multirow[t]{2}{*}{ night } & $7.9(5.4-10.4)$ & $11.6(10.2-13.0)$ & $13.4(13.0-13.8)$ & $14.6(13.3-15.9)$ \\
\hline & \multicolumn{4}{|c|}{ Median PAR $\left(\mu \mathrm{mol} \mathrm{m} \mathrm{m}^{-2} \mathrm{~s}^{-1}\right)$} \\
\hline all & $212(140-284)$ & $511(373-650)$ & $239(174-303)$ & $279(178-380)$ \\
\hline \multirow[t]{2}{*}{ day } & 767 (599-935) & $1192(1068-1295)$ & $706(588-823)$ & $762(636-888)$ \\
\hline & \multicolumn{4}{|c|}{ Emission-temperature correlation } \\
\hline all & $0.45(0.31-0.57)$ & $0.54(0.42-0.64)$ & $0.43(0.30-0.54)$ & $0.56(0.42-0.67)$ \\
\hline day & - & $0.57(0.34-0.74)$ & $0.48(0.23-0.67)$ & $0.66(0.42-0.82)$ \\
\hline \multirow[t]{2}{*}{ night } & $0.45(0.09-0.71)$ & - & - & $0.55(0.19-0.78)$ \\
\hline & \multicolumn{4}{|c|}{ Emission-PAR correlation } \\
\hline all & $0.50(0.37-0.61)$ & $0.49(0.36-0.60)$ & $0.42(0.29-0.53)$ & $0.50(0.35-0.62)$ \\
\hline \multirow[t]{2}{*}{ day } & $0.44(0.15-0.66)$ & $0.35(0.06-0.58)$ & $0.38(0.10-0.60)$ & $0.51(0.21-0.72)$ \\
\hline & \multicolumn{4}{|c|}{ Temperature-PAR correlation } \\
\hline all & $0.24(0.08-0.38)$ & $0.55(0.43-0.65)$ & $0.63(0.53-0.71)$ & $0.58(0.45-0.69)$ \\
\hline \multirow[t]{2}{*}{ day } & - & $0.56(0.32-0.73)$ & $0.55(0.31-0.72)$ & $0.68(0.45-0.83)$ \\
\hline & \multicolumn{4}{|c|}{ Number of measurements } \\
\hline all & 151 & 159 & 176 & 117 \\
\hline day & 40 & 45 & 48 & 35 \\
\hline night & 28 & 27 & 40 & 24 \\
\hline
\end{tabular}

monoterpene emissions were partly light dependent. This result suggests that the role of de novo biosynthesis was observable. However, it can also be an indication of the correlation between PAR and the needle temperature. Then both storage pools and biosynthesis could have contributed to the light dependent increase in the emissions.

\subsection{Emission potentials and the role of de novo emissions}

Between May and August, the emission potential decreased from 1100 to $630 \mu \mathrm{g} \mathrm{m}^{-2} \mathrm{~h}^{-1}$ in the hybrid algorithm and from 810 to $500 \mu \mathrm{g} \mathrm{m}^{-2} \mathrm{~h}^{-1}$ in the pool algorithm (Fig. 3). The trend was statistically significant in both cases, indicating that the potential of the forest to emit monoterpenes diminished over the summer. A similar decline in the pool emission potential has been observed also in shoot scale measurements at the same site (Tarvainen et al., 2005; Hakola et al., 2006). For example, the results of Hakola et al. (2006) correspond fairly well with our ecosystem scale pool emission potential (Fig. 3a). Thus, concordant with the conjecture in the previous section, the monoterpene emissions seem to have originated mainly from the canopy also in view of the emission potentials. August was an exception with a higher ecosystem scale result, reflecting that other sources possibly had a more central role in late summer.

According to the pool algorithm, our results suggest that the monoterpene diffusion rate from the storage pools into the atmosphere decreased towards the late summer, probably due to changes in the diffusivity of this pathway or in the monoterpene composition. A substantial diminution of the pool size seems unlikely as the storage in needles typically exceeds the annual emission at least by five times (see e.g. Rinne et al., 2009). The trend in the total emission potential 


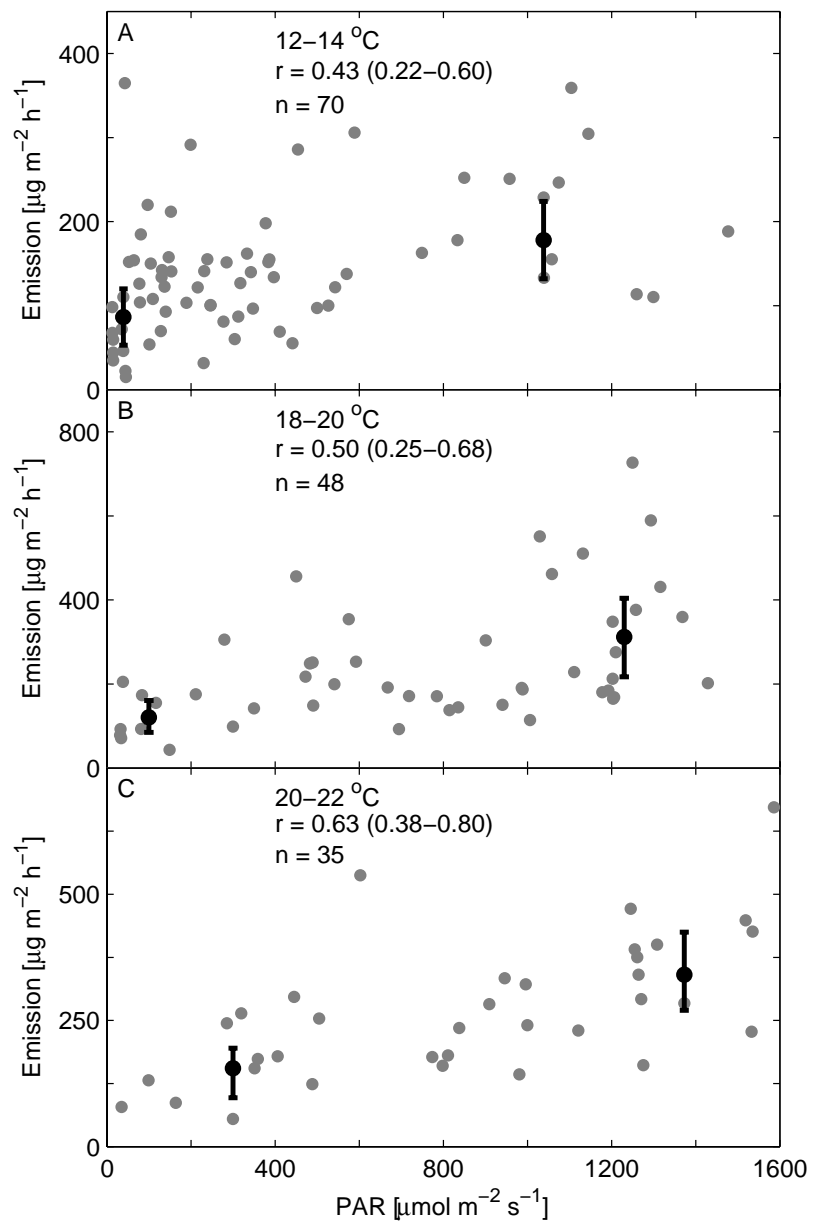

Fig. 2. Monoterpene emissions as a function of photosynthetically active radiation (PAR) in three temperature ranges. The grey dots show the individual measurements, $r$ is the correlation coefficient, and $n$ is the number of measurements. The black dots show the medians for the observations at low PAR (below the 25th percentile) and high PAR (above the 75th percentile). The numbers in parentheses and the error bars represent the $95 \%$ confidence intervals. Only observations at PAR higher than $10 \mu \mathrm{mol} \mathrm{m}^{-2} \mathrm{~s}^{-1}$ were included in the analysis.

can also reflect seasonal variation in monoterpene biosynthesis in Scots pine. Without further evidence, it is probably safest to assign the decrease in both emission potentials to changes in Scots pine, not forgetting that emissions from the undergrowth, litter, and soil can occasionally be substantial at the site (Hellén et al., 2006). Root-associated fungi occurring in boreal forest soils are an interesting and yet rather unexplored monoterpene source, even though their emissions appear to be dominated by oxygenated VOCs (Bäck et al., 2010).

Figure $3 \mathrm{~b}$ shows the outcome of our approach to assessing the role of biosynthesis at the ecosystem scale. The ratio of the de novo emission potential to the total emission potential ranged between $30 \%(7-52 \%)$ and $46 \%$ (22-69\%).

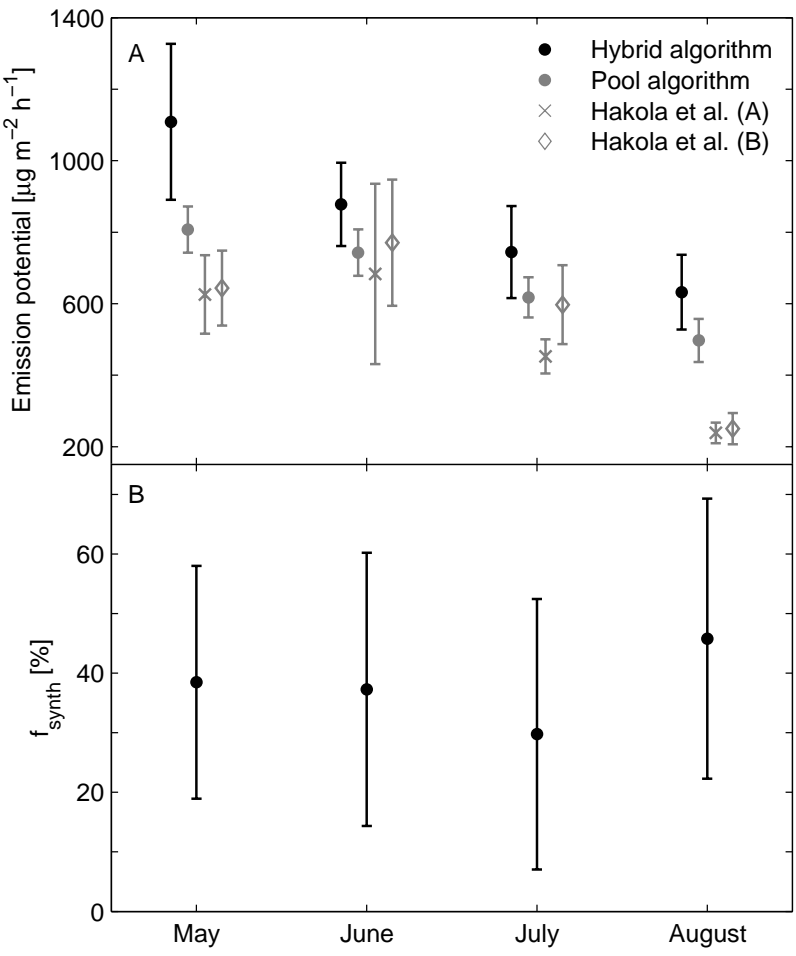

Fig. 3. (A) Monthly variation in the total emission potential and the pool emission potential during the summer 2007. The pool emission potentials based on measurements with two Scots pine branches were derived from the results of Hakola et al. (2006) using a needle biomass density of $540 \mathrm{~g} \mathrm{~m}^{-2}$. (B) Ratio of the de novo emission potential to the total emission potential ( $\left.f_{\text {synth }}\right)$. The error bars represent the $95 \%$ confidence intervals.

The monthly changes were not significant at the $95 \%$ confidence level and hence the seasonal variation in biosynthesis (Fischbach, 2001) could not be determined from our results. However, the ratio always differed statistically from zero, thus suggesting that de novo biosynthesis had a significant role in the ecosystem scale monoterpene emissions.

The contribution of de novo emissions was lower, although not significantly, than in the shoot scale measurements of Ghirardo et al. (2010). Their result for Scots pine saplings was $58 \%$, which does not differ from our results when the uncertainties in both studies are taken into account. The age and habitat of the trees, the season, and the measurement scale could probably explain even a more pronounced difference. In addition to the mature Scots pine trees, the ecosystem scale measurements included emissions from the undergrowth, litter, and soil. It is also possible that emissions from bark, presumably originating mainly from pools, had a stronger effect at the ecosystem scale than for the saplings.

This study probably presents the first direct attempt to estimate the importance of biosynthesis in ecosystem scale monoterpene emissions. The analysis revealed significant correlations between the emissions and PAR, but the 


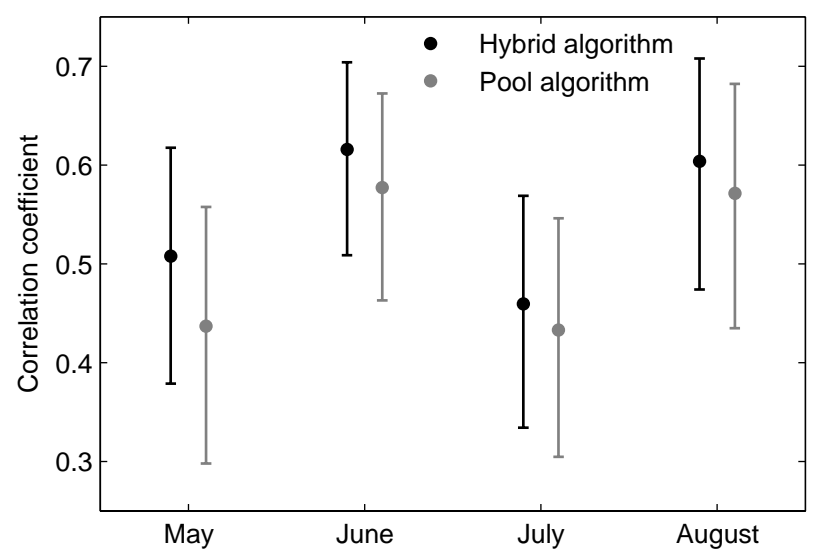

Fig. 4. Monthly correlations between the measured monoterpene emissions and the emissions given by the two algorithms during the summer 2007. The error bars show the $95 \%$ confidence intervals.

estimates of the contribution of de novo emissions were sensitive to the amount of data and thus highly uncertain. For example, when the amount of data was reduced by applying flux quality criteria or using only daytime measurements, the hybrid algorithm produced results which did not demonstrate a significant contribution from biosynthesis at the $95 \%$ confidence level. Despite this sensitivity to the amount of data, the results in Fig. 3 were reproducible in the sense that they were independent of the initial values in the non-linear regression analysis.

\subsection{Implication for emission modelling}

Figure 4 shows the correlations between the measured emissions and the emissions given by the two algorithms. The range of the correlation coefficient was $0.46-0.62$ for the hybrid algorithm and $0.43-0.58$ for the pool algorithm. The seasonal changes and the differences between the algorithms were not significant. In this sense, the algorithms performed equally well. However, they should be contrasted with independent measurements to get more reliable estimates of their performance and predictive power. By employing an independent value for the proportion of de novo emissions, Ghirardo et al. (2010) observed that the hybrid algorithm captured diurnal variation in ecosystem scale emissions somewhat better than the pool algorithm, reducing especially night-time overestimation.

Recently, there has been a debate on whether processbased or semi-empirical algorithms should be used when modelling monoterpene emissions at different scales (Grote and Niinemets, 2008; Niinemets et al., 2010a,b). Our results are inadequate for such speculation, but previous laboratory experiments have clearly demonstrated the substantial contribution of both pool and de novo emissions from Scots pine (Shao et al., 2001; Ghirardo et al., 2010). Thus hybrid algorithms seem biologically more realistic than pool algorithms.
In recent emission inventories for Europe (Karl et al., 2009; Keenan et al., 2009), for instance, the contribution of de novo monoterpene emissions from Scots pine has already been taken into account by using hybrid algorithms. However, the partition between pool and de novo emissions is still poorly known. The work of Ghirardo et al. (2010) gave the first quantitative result, now complemented by our more qualitative assessment at the ecosystem scale. Seasonal changes in the partition as well as the detailed structure of a sound and practical hybrid algorithm remain as important research objectives.

\section{Conclusions}

Our analysis based on the DEC measurements above a boreal Scots pine dominated forest revealed five features of the ecosystem scale monoterpene emissions.

1. The emissions peaked in June, otherwise their monthly medians remained essentially constant during the measurement period May-August 2007. The monthly medians of PAR showed similar behaviour while the monthly median temperatures had an increasing trend.

2. The emissions were partly light dependent, which probably was an indication of the role of de novo biosynthesis.

3. Both the hybrid and pool algorithm demonstrated that the monoterpene emission potential decreased over the summer. These ecosystem scale results were concordant with the trend in the pool emission potential derived from previous shoot scale measurements.

4. The ratio of the de novo emission potential to the total emission potential differed significantly from zero throughout the summer. However, more reliable estimates of the contribution of de novo emissions are needed for improving monoterpene emission algorithms.

5. In this study, the hybrid algorithm did not perform statistically better than the traditional pool algorithm.

Although highly accurate estimates were not achieved in this work, the results of ${ }^{13} \mathrm{CO}_{2}$ labelling experiments (Shao et al., 2001; Ghirardo et al., 2010) have clearly shown the significance of de novo emissions. Given this strong biological support, we recommend comparing hybrid and pool algorithms when modelling monoterpene emissions from Scots pine dominated forests.

Acknowledgements. We thank V. Henriksson for his help with the data analysis and the staff of the SMEAR II station for their assistance in the measurements. We acknowledge the Academy of Finland (120434, 125238, 209216, and 1118615), the European Integrated Project on Aerosol-Cloud-Climate and Air Quality 
Interactions (EUCAARI), the Helsinki University Centre for Environment (Urban and Rural Air Pollution Consortium), the Kone Foundation, and the Marie Curie Industry-Academia Partnerships and Pathways action of the European Commission (IAPP, 218065, P7440-015-015) for financial support.

Edited by: A. Arneth

\section{References}

Arneth, A., Monson, R. K., Schurgers, G., Niinemets, Ü., and Palmer, P. I.: Why are estimates of global terrestrial isoprene emissions so similar (and why is this not so for monoterpenes)?, Atmos. Chem. Phys., 8, 4605-4620, doi:10.5194/acp-8-46052008, 2008.

Bäck, J., Hari, P., Hakola, H., Juurola, E., and Kulmala, M.: Dynamics of monoterpene emissions in Pinus sylvestris during early spring, Boreal Environ. Res., 10, 409-424, 2005.

Bäck, J., Aaltonen, H., Hellén, H., Kajos, M. K., Patokoski, J., Taipale, R., Pumpanen, J., and Heinonsalo, J.: Variable emissions of microbial volatile organic compounds (MVOCs) from root-associated fungi isolated from Scots pine, Atmos. Environ., 44, 3651-3659, 2010.

Bamberger, I., Hörtnagl, L., Schnitzhofer, R., Graus, M., Ruuskanen, T. M., Müller, M., Dunkl, J., Wohlfahrt, G., and Hansel, A.: BVOC fluxes above mountain grassland, Biogeosciences, 7 , 1413-1424, doi:10.5194/bg-7-1413-2010, 2010.

Blake, R. S., Monks, P. S., and Ellis, A. M.: Proton-transfer reaction mass spectrometry, Chem. Rev., 109, 861-896, 2009.

Brunner, A., Ammann, C., Neftel, A., and Spirig, C.: Methanol exchange between grassland and the atmosphere, Biogeosciences, 4, 395-410, doi:10.5194/bg-4-395-2007, 2007.

Davison, B., Taipale, R., Langford, B., Misztal, P., Fares, S., Matteucci, G., Loreto, F., Cape, J. N., Rinne, J., and Hewitt, C. $\mathrm{N}$.: Concentrations and fluxes of biogenic volatile organic compounds above a Mediterranean macchia ecosystem in western Italy, Biogeosciences, 6, 1655-1670, doi:10.5194/bg-6-16552009, 2009.

de Gouw, J. and Warneke, C.: Measurements of volatile organic compounds in the Earth's atmosphere using proton-transferreaction mass spectrometry, Mass Spectrom. Rev., 26, 223-257, 2007.

Fischbach, R.: Monoterpensynthasen in Blättern der Fichte (Picea abies (L.) Karst.) und der Steineiche (Quercus ilex L.), Ph.D. thesis, University of Freiburg, Germany, 188 pp., 2001.

Ghirardo, A., Koch, K., Taipale, R., Zimmer, I., Schnitzler, J.-P., and Rinne, J.: Determination of de novo and pool emissions of terpenes from four common boreal/alpine trees by ${ }^{13} \mathrm{CO}_{2}$ labelling and PTR-MS analysis, Plant Cell Environ., 33, 781-792, 2010.

Grote, R. and Niinemets, Ü.: Modeling volatile isoprenoid emissions - a story with split ends, Plant Biol., 10, 8-28, 2008.

Grote, R., Mayrhofer, S., Fischbach, R. J., Steinbrecher, R., Staudt, M., and Schnitzler, J.-P.: Process-based modelling of isoprenoid emissions from evergreen leaves of Quercus ilex (L.), Atmos. Environ., 40, S152-S165, 2006.

Guenther, A.: Seasonal and spatial variations in natural volatile organic compound emissions, Ecol. Appl., 7(1), 34-45, 1997.
Guenther, A. B., Monson, R. K., and Fall, R.: Isoprene and monoterpene emission rate variability: Observations with eucalyptus and emission rate algorithm development, J. Geophys. Res., 96(D6), 10799-10808, 1991.

Guenther, A. B., Zimmerman, P. R., Harley, P. C., Monson, R. K., and Fall, R.: Isoprene and monoterpene emission rate variability: Model evaluations and sensitivity analyses, J. Geophys. Res., 98(D7), 12609-12617, 1993.

Haapanala, S., Ekberg, A., Hakola, H., Tarvainen, V., Rinne, J., Hellén, H., and Arneth, A.: Mountain birch - potentially large source of sesquiterpenes into high latitude atmosphere, Biogeosciences, 6, 2709-2718, doi:10.5194/bg-6-2709-2009, 2009.

Hakola, H., Tarvainen, V., Bäck, J., Ranta, H., Bonn, B., Rinne, J., and Kulmala, M.: Seasonal variation of mono- and sesquiterpene emission rates of Scots pine, Biogeosciences, 3, 93-101, doi:10.5194/bg-3-93-2006, 2006.

Hallquist, M., Wenger, J. C., Baltensperger, U., Rudich, Y., Simpson, D., Claeys, M., Dommen, J., Donahue, N. M., George, C., Goldstein, A. H., Hamilton, J. F., Herrmann, H., Hoffmann, T., Iinuma, Y., Jang, M., Jenkin, M. E., Jimenez, J. L., Kiendler-Scharr, A., Maenhaut, W., McFiggans, G., Mentel, Th. F., Monod, A., Prévôt, A. S. H., Seinfeld, J. H., Surratt, J. D., Szmigielski, R., and Wildt, J.: The formation, properties and impact of secondary organic aerosol: current and emerging issues, Atmos. Chem. Phys., 9, 5155-5236, doi:10.5194/acp-95155-2009, 2009.

Hansel, A., Jordan, A., Holzinger, R., Prazeller, P., Vogel, W., and Lindinger, W.: Proton transfer reaction mass spectrometry: online trace gas analysis at the ppb level, Int. J. Mass Spectrom., 149/150, 609-619, 1995.

Hari, P. and Kulmala, M.: Station for Measuring EcosystemAtmosphere Relations (SMEAR II), Boreal Environ. Res., 10, 315-322, 2005.

Hellén, H., Hakola, H., Pystynen, K.-H., Rinne, J., and Haapanala, S.: C2-C10 hydrocarbon emissions from a boreal wetland and forest floor, Biogeosciences, 3, 167-174, doi:10.5194/bg-3-1672006, 2006.

Holst, T., Arneth, A., Hayward, S., Ekberg, A., Mastepanov, M., Jackowicz-Korczynski, M., Friborg, T., Crill, P. M., and Bäckstrand, K.: BVOC ecosystem flux measurements at a high latitude wetland site, Atmos. Chem. Phys., 10, 1617-1634, doi:10.5194/acp-10-1617-2010, 2010.

Holzinger, R., Lee, A., McKay, M., and Goldstein, A. H.: Seasonal variability of monoterpene emission factors for a ponderosa pine plantation in California, Atmos. Chem. Phys., 6, 1267-1274, doi:10.5194/acp-6-1267-2006, 2006.

Janson, R. W.: Monoterpene emissions from Scots pine and Norwegian spruce, J. Geophys. Res., 98(D2), 2839-2850, 1993.

Junninen, H., Lauri, A., Keronen, P., Aalto, P., Hiltunen, V., Hari, P., and Kulmala, M.: Smart-SMEAR: on-line data exploration and visualization tool for SMEAR stations, Boreal Environ. Res., 14, 447-457, 2009.

Karl, M., Guenther, A., Köble, R., Leip, A., and Seufert, G.: A new European plant-specific emission inventory of biogenic volatile organic compounds for use in atmospheric transport models, Biogeosciences, 6, 1059-1087, doi:10.5194/bg-6-1059-2009, 2009.

Karl, T. G., Spirig, C., Rinne, J., Stroud, C., Prevost, P., Greenberg, J., Fall, R., and Guenther, A.: Virtual disjunct eddy covariance measurements of organic compound fluxes from a subalpine 
forest using proton transfer reaction mass spectrometry, Atmos. Chem. Phys., 2, 279-291, doi:10.5194/acp-2-279-2002, 2002.

Keenan, T., Niinemets, Ü., Sabate, S., Gracia, C., and Peñuelas, J.: Process based inventory of isoprenoid emissions from European forests: model comparisons, current knowledge and uncertainties, Atmos. Chem. Phys., 9, 4053-4076, doi:10.5194/acp-94053-2009, 2009.

Langford, B., Misztal, P. K., Nemitz, E., Davison, B., Helfter, C., Pugh, T. A. M., MacKenzie, A. R., Lim, S. F., and Hewitt, C. N.: Fluxes and concentrations of volatile organic compounds from a South-East Asian tropical rainforest, Atmos. Chem. Phys., 10, 8391-8412, doi:10.5194/acp-10-8391-2010, 2010.

Lindinger, W., Hansel, A., and Jordan, A.: On-line monitoring of volatile organic compounds at pptv levels by means of ProtonTransfer-Reaction Mass Spectrometry (PTR-MS) - Medical applications, food control and environmental research, Int. J. Mass Spectrom., 173, 191-241, 1998.

Misztal, P. K., Owen, S. M., Guenther, A. B., Rasmussen, R., Geron, C., Harley, P., Phillips, G. J., Ryan, A., Edwards, D. P., Hewitt, C. N., Nemitz, E., Siong, J., Heal, M. R., and Cape, J. N.: Large estragole fluxes from oil palms in Borneo, Atmos. Chem. Phys., 10, 4343-4358, doi:10.5194/acp-10-4343-2010, 2010.

Niinemets, Ü., Seufert, G., Steinbrecher, R., and Tenhunen, J. D.: A model coupling foliar monoterpene emissions to leaf photosynthetic characteristics in Mediterranean evergreen Quercus species, New Phytol., 153, 257-275, 2002.

Niinemets, Ü., Arneth, A., Kuhn, U., Monson, R. K., Peñuelas, J., and Staudt, M.: The emission factor of volatile isoprenoids: stress, acclimation, and developmental responses, Biogeosciences, 7, 2203-2223, doi:10.5194/bg-7-2203-2010, 2010a.

Niinemets, Ü., Monson, R. K., Arneth, A., Ciccioli, P., Kesselmeier, J., Kuhn, U., Noe, S. M., Peñuelas, J., and Staudt, M.: The leaflevel emission factor of volatile isoprenoids: caveats, model algorithms, response shapes and scaling, Biogeosciences, 7, 18091832, doi:10.5194/bg-7-1809-2010, 2010b.

Räisänen, T., Ryyppö, A., and Kellomäki, S.: Monoterpene emission of a boreal Scots pine (Pinus sylvestris L.) forest, Agr. Forest Meteorol., 149, 808-819, 2009.

Rinne, H. J. I., Guenther, A. B., Warneke, C., de Gouw, J. A., and Luxembourg, S. L.: Disjunct eddy covariance technique for trace gas flux measurements, Geophys. Res. Lett., 28(16), 3139-3142, 2001.

Rinne, J., Hakola, H., Laurila, T., and Rannik, Ü.: Canopy scale monoterpene emissions of Pinus sylvestris dominated forests, Atmos. Environ., 34, 1099-1107, 2000.

Rinne, J., Taipale, R., Markkanen, T., Ruuskanen, T. M., Hellén, H., Kajos, M. K., Vesala, T., and Kulmala, M.: Hydrocarbon fluxes above a Scots pine forest canopy: measurements and modeling, Atmos. Chem. Phys., 7, 3361-3372, doi:10.5194/acp-73361-2007, 2007.

Rinne, J., Bäck, J., and Hakola, H.: Biogenic volatile organic compound emissions from the Eurasian taiga: current knowledge and future directions, Boreal Environ. Res., 14, 807-826, 2009.

Ruuskanen, T. M., Kolari, P., Bäck, J., Kulmala, M., Rinne, J., Hakola, H., Taipale, R., Raivonen, M., Altimir, N., and Hari, P.: On-line field measurements of monoterpene emissions from Scots pine by proton-transfer-reaction mass spectrometry, Boreal Environ. Res., 10, 553-567, 2005.
Schuh, G., Heiden, A. C., Hoffmann, Th., Kahl, J., Rockel, P., Rudolph, J., and Wildt, J.: Emissions of volatile organic compounds from sunflower and beech: Dependence on temperature and light intensity, J. Atmos. Chem., 27, 291-318, 1997.

Schurgers, G., Arneth, A., Holzinger, R., and Goldstein, A. H.: Process-based modelling of biogenic monoterpene emissions combining production and release from storage, Atmos. Chem. Phys., 9, 3409-3423, doi:10.5194/acp-9-3409-2009, 2009.

Seber, G. A. F. and Wild, C. J.: Nonlinear Regression, John Wiley \& Sons, Inc., New York, United States, 1989.

Shao, M., Czapiewski, K. V., Heiden, A. C., Kobel, K., Komenda, M., Koppmann, R., and Wildt, J.: Volatile organic compound emissions from Scots pine: Mechanisms and description by algorithms, J. Geophys. Res., 106(D17), 20483-20491, 2001.

Spanke, J., Rannik, Ü., Forkel, R., Nigge, W., and Hoffmann, T.: Emission fluxes and atmospheric degradation of monoterpenes above a boreal forest: field measurements and modelling, Tellus, 53B, 406-422, 2001.

Spirig, C., Neftel, A., Ammann, C., Dommen, J., Grabmer, W., Thielmann, A., Schaub, A., Beauchamp, J., Wisthaler, A., and Hansel, A.: Eddy covariance flux measurements of biogenic VOCs during ECHO 2003 using proton transfer reaction mass spectrometry, Atmos. Chem. Phys., 5, 465-481, doi:10.5194/acp-5-465-2005, 2005.

Steinbrecher, R., Hauff, K., Hakola, H., and Rössler, J.: A revised parameterisation for emission modelling of isoprenoids for boreal plants, in: Biogenic VOC emissions and photochemistry in the boreal regions of Europe, edited by: Laurila, T. and Lindfors, V., Air Pollution Research Report, 70, Commission of the European Communities, Luxembourg, 29-43, 1999.

Taipale, R., Ruuskanen, T. M., Rinne, J., Kajos, M. K., Hakola, H., Pohja, T., and Kulmala, M.: Technical Note: Quantitative long-term measurements of VOC concentrations by PTR-MS measurement, calibration, and volume mixing ratio calculation methods, Atmos. Chem. Phys., 8, 6681-6698, doi:10.5194/acp8-6681-2008, 2008.

Taipale, R., Ruuskanen, T. M., and Rinne, J.: Lag time determination in DEC measurements with PTR-MS, Atmos. Meas. Tech., 3, 853-862, doi:10.5194/amt-3-853-2010, 2010.

Tarvainen, V., Hakola, H., Hellén, H., Bäck, J., Hari, P., and Kulmala, M.: Temperature and light dependence of the VOC emissions of Scots pine, Atmos. Chem. Phys., 5, 989-998, doi:10.5194/acp-5-989-2005, 2005.

Tingey, D. T., Manning, M., Grothaus, L. C., and Burns, W. F.: Influence of light and temperature on monoterpene emission rates from slash pine, Plant Physiol., 65, 797-801, 1980.

Tunved, P., Hansson, H.-C., Kerminen, V.-M., Ström, J., Dal Maso, M., Lihavainen, H., Viisanen, Y., Aalto, P. P., Komppula, M., and Kulmala, M.: High natural aerosol loading over boreal forests, Science, 312, 261-263, 2006.

Warneke, C., Luxembourg, S. L., de Gouw, J. A., Rinne, H. J. I., Guenther, A. B., and Fall, R.: Disjunct eddy covariance measurements of oxygenated volatile organic compounds fluxes from an alfalfa field before and after cutting, J. Geophys. Res., 107(D8), 4067, doi:10.1029/2001JD000594, 2002. 